\title{
Az életkor szerepének retrospektív vizsgálata a bölcsességfogak eltávolításában
}

\author{
DR. PAPP ZSÓFIA KRISZTINA, DR. SZMIRNOV GYÖRGY, \\ DR. CSOMÓ KRISZTIÁN, DR. IVÁNYI ATTILA, DR. JOÓB-FANCSALY ÁRPÁD
}

\begin{abstract}
Vizsgálatunk célja az volt, hogy nemzetközi eredményekkel összehasonlítsuk a bölcsességfogak klinikánkon folyó eltávolításának időpontját. Adataink 10 év munkáját, a 2010-2019 közötti időszakot fedik át. A fent nevezett időszakban 5 és 95 év közötti pácienseknél összesen 23305 bölcsességfogat távolítottunk el. A kapott adatokat összehasonlítottuk a nemzetközi adatokkal is. Azt találtuk, hogy nők esetében jóval gyakrabban (61,5\%) végeztünk bölcsességfog-eltávolítást, mint férfiaknál (38,5\%), ellentétben a külföldi adatokkal [25]. Az esetek majdnem kétharmadában (60,7\%) alsó bölcsességfogat távolítottunk el. Mind az alsó, mind a felső bölcsességfogak esetében a 24 éves kor volt az eltávolítás legjellemzőbb időpontja. Életkor szerinti összehasonlításban nem találtunk szignifikáns különbséget sem az alsó és felső bölcsességfogak eltávolításai esetében $(p=0,412)$, sem a négy különböző kvadránsban végzett beavatkozások között $(p=0,117)$. Az adatgyújtés és a klinikai kódrendszer heterogenitása miatt a pontos diagnózisról és a fogeltávolítás módjáról (egyszerű fogeltávolítás vagy sebészi úton történő fogeltávolítás) statisztikailag elemezhető adathalmaz nem állt rendelkezésünkre.
\end{abstract}

Kulcsszavak: bölcsességfog; eltávolítás; életkor; eloszlás; nem

\section{Bevezetés}

A bölcsességfogak mútéti eltávolítása az egyik leggyakrabban végzett ambuláns dentoalveoláris szájsebészeti beavatkozás [5, 22]. A bölcsességfogak számítanak a leggyakrabban eltávolított fogaknak, illetve ezeknek az extrahálása igényel leggyakrabban sebészi módszert [25]. Az ilyen jellegű beavatkozások száma évről évre nő, klinikánkon 2001 és 2016 között megháromszorozódott az eltávolított impaktált bölcsességfogak száma [22, 28]. A bölcsességfogak kivételének fő indikációi közt szerepelnek a gyulladásos elváltozások, szuvasodás, cysták, odontogén daganatok kialakulása, illetve a szomszédos fogak és a környező csontszövet destrukciója [26]. A fő indikációk korosztályonként jelentős eltérést mutathatnak. A fiatalkori bölcsességfog-eltávolítás leggyakoribb indikációi a profilaktikus vagy orthodontiai célú extractio, az impactio és a pericoronitis. A Semmelweis Egyetem Fogorvstudományi Kar, Orális Diagnosztikai Tanszék Dento-alveoláris Sebészeti Osztályán 20162017 között a bölcsességfogak több mint 60\%-a orthodontiai vagy preventív céllal került eltávolításra [17]. Európában a fiatal felnőttek $73 \%$-ánál, Svédországban a 20-30 év közöttiek 72\%-ánál, Japánban az állampolgárok $30 \%$-ánál találtak legalább egy impaktált bölcsességfogat [7, 13, 42, 44]. Líbiában egy 21 éves átlag életkorú diákpopuláció 93,5\%-ánál diagnosztizálták mind a négy bölcsességfog impactióját. Adeyemo és mtsai vizsgálata során a bölcsességfogak eltávolításának hátterében 9,2\%-ban akut-, 26,3\%-ban krónikus pericoronitis állt [2]. A görög katonaság körében végzett kutatás során a pericoronitis előfordulási gyakorisága 4,92\%-nak mutatkozott, a vizsgált páciensek 72\%-ban 20-25 év közötti fiatalok voltak [24]. Az életkor előrehaladtával az eltávolítás fő okává a caries és a parodontitis válnak [14, 16, 27, 31, 38]. Erre mutat rá az Al Ogayel és mtsai által írt tanulmány is, ahol a Szaúd-Arábiában végzett vizsgálataik során a bölcsességfogak $31 \%$-ánál diagnosztizáltak szuvasodást, illetve ezzel összefüggésben lévő pulpalis folyamatok során kialakult patológiás elváltozásokat [4]. Fontos megjegyezni, hogy a caries nem csak a nehezen tisztítható bölcsességfogak esetében, hanem a szomszédos fogakon is gyakran kialakul. Ezt támasztja alá Linden és mtsai publikációja is, ahol a bölcsességfogak 7,1\%-ánál, míg a szomszédos fogak esetében 42,7\%-ban diagnosztizáltak radiológiai felvételek alapján cariest. Vizsgálataik alapján parodontális károsodás leggyakrabban az alsó bölcsességfogakkal összefüggésben alakult ki, a jellegzetes radiológiai kép a második és harmadik moláris fog közötti interproximális csont magasságának csökkenése volt [46]. Összességében nézve a terápiás indikációkat, a panaszt okozó bölcsességfogak hátterében a pericoronitis után leggyakrabban a fog szuvasodása, illetve az ebből kiinduló gyulladásos folyamatok állnak, melyek esetenként a szomszédos fogakat is érin- 
tik [17]. Finnországban az általános gyakorlat szerint az azonos oldali bölcsességfogak egymástól elkülönülten, 1.2 év különbséggel kerülnek eltávolításra. Számos tanulmány szerint a bölcsességfogak kétharmada az emberek 30-40 éves korára már eltávolításra került [25]. $A z$ áttörésben teljesen vagy részlegesen visszamaradt bölcsességfogak eltávolítása gyakran jár együtt intraoperatív komplikációkkal, illetve korai vagy késői szövődményekkel. Hogy ezeket elkerülhessük, körültekintően kell eljárnunk a kezelési mód megválasztását és a beavatkozás időzítését illetően. Számos tanulmány szerint a bölcsességfogak eltávolításának leggyakoribb szövődményei az ostitis alveolaris és a posztoperatív gyulladások. Az alsó bölcsességfogak eltávolítása után - irodalmi adatok alapján - az esetek 2,6-30,9\%-ban lépnek fel komplikációk [33]. A sebész tapasztalatlanságához, az időben elhúzódó mútéthez, a dohányzáshoz és számos egyéb predisponáló faktorhoz hasonlóan a posztoperatív szövődmények kialakulásának gyakoriságában szerepet játszik a páciens életkorának növekedése. A bölcsességfogakhoz társuló patológiás elváltozások (cysták, odontogén daganatok, szuvasodás, parodontális károsodás) kialakulásának valószínűsége szintén nő az életkorral, így az ideális extractiós életkorok meghatározása és a bizonyítékokon alapuló tudás mindennapi fogorvosi gyakorlatba való átültetése kulcsfontosságú [33]. Jelen vizsgálat célja az elmúlt 10 év alatt klinikánkon bölcsességfog-eltávolításon átesett páciensek életkorának statisztikai összegzése, elemzése és az eredmények nemzetközi szakirodalmi adatokkal való öszszehasonlítása volt.

\section{Vizsgálati anyag és módszer}

A Fogász ${ }^{\circledR}$ betegnyilvántartó programban regisztrált adataink 2010. január 1. és 2019. szeptember 30. közötti időszakból származnak. A Semmelweis Egyetem Fogorvostudományi Kar, Arc-, Állcsont-, Szájsebészeti és Fogászati Klinikája az egyik legnagyobb beutaló köteles járó-, és fekvőbeteg-ellátást végző szakellátó egység Magyarországon, ahol évente több mint 44 ezer beteg ellátása történik. Az ország egész területéről fogadunk és kezelünk pácienseket. Retrospektív vizsgálatunkhoz Excel-táblázat alapú adatbázisokat használtunk fel, melyek kizárólag a klinikán elvégzett bölcsességfog-eltávolításokat tartalmazzák, a különböző nemek, születési idő, az eltávolítás pontos időpontja, illetve a bölcsességfog pozíciójának jelölése alapján. A bölcsességfogak egy része a dokumentációban szereplő kezelőorvos által, a másik része a III., IV. és V. éves fogorvostan-hallgatók szájsebészeti oktatásának keretén belül került eltávolításra. Kétmintás t-próbával összehasonlítottuk, hogy életkor alapján van-e különbség az alsó és felső bölcsességfogak eltávolítása között, illetve ANOVA próba során szignifikáns különbséget kerestünk életkor szerint a 4 kvadráns bölcsességfogainak eltávolítása között. A vizsgálatunk során alkalmazott statisztikai módszereknél 95\%-os konfidencia-intervallum mellett a szignifikancia szint $p \leq 0,05$ volt.

\section{Eredmények}

Majdnem 10 éves periódus alatt 23305 bölcsességfog került eltávolításra klinikánk munkatársai által (Táblázat).

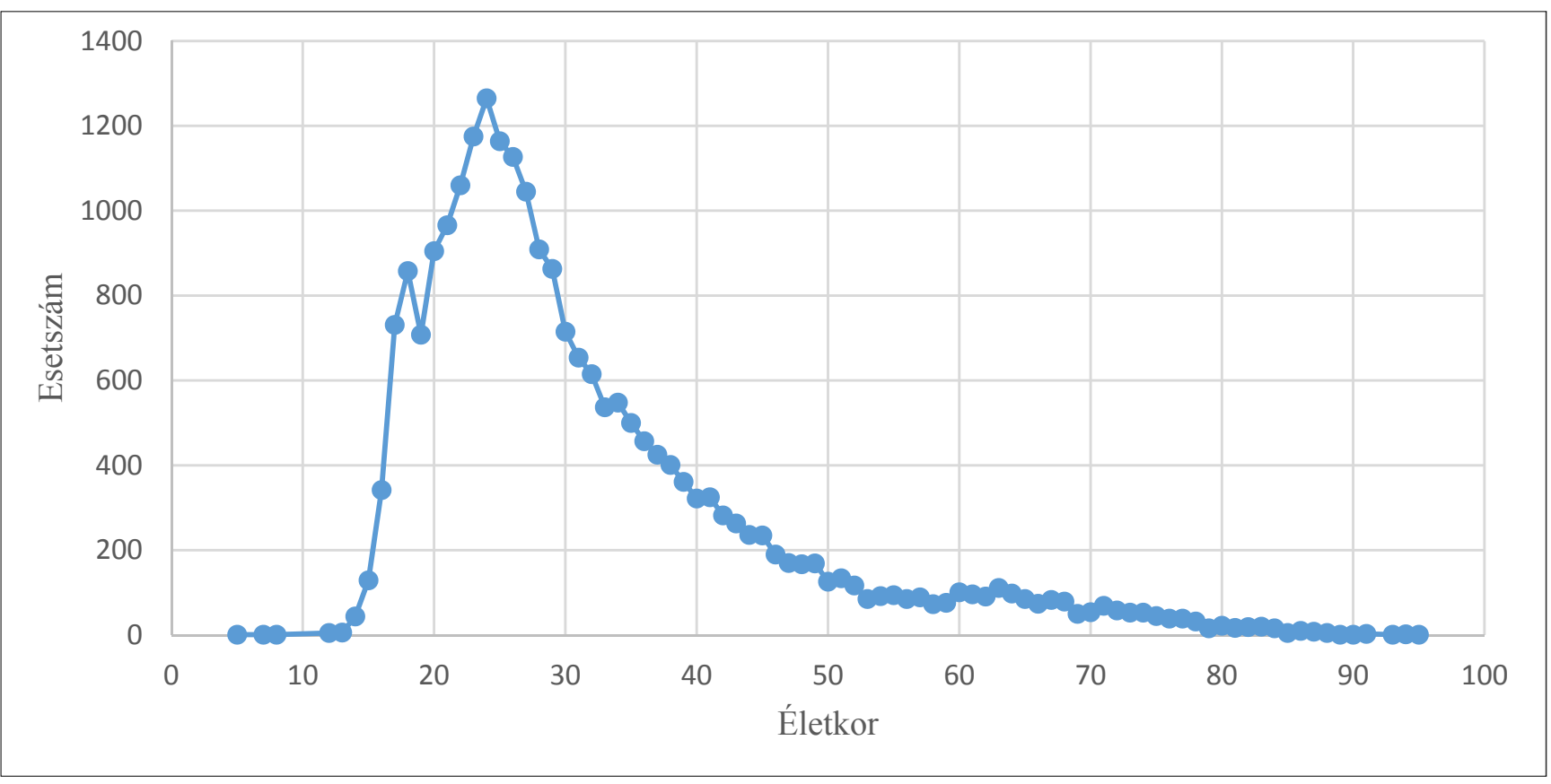

1. kép: A Semmelweis Egyetem Fogorvostudományi Kar, Arc-, Állcsont-, Szájsebészeti és Fogászati Klinikán 2010-től 2019-ig bölcsességfog eltávolításon átesett páciensek koreloszlása 
A vizsgálatba bevont pácienseink 5 és 95 éves kor között voltak reprezentálva és az esetek alig kétharmadában nők voltak (61,5\%). Mind az alsó, mind a felső bölcsességfogak esetében az eltávolításkor az átlagéletkor 31,7 év volt (szórás: 13432), a medián életkor 28 év, míg az életkorok módusza 24 év volt (1265 bölcsességfog). Az életkori módusznak számító 24 éves kort követi szorosan a 23. életév (1175 bölcsességfog) és 25 éves kor (1164 bölcsességfog). Az átlagéletkornak számító 31 éves korban összesen 654 extractiót végeztük. Az esetek 61\%-ában alsó, illetve 39\%-ában felső bölcsességfogakat távolítottunk el. Életkor szerinti összehasonlítás során sem az alsó és felső bölcsességfog extractiók esetében ( $p=0,412)$, sem a 4 kvadránsban végzett beavatkozások között nem találtunk szignifikáns különbséget $(\mathrm{p}=0,117)$. (1-3. kép)

\section{Megbeszélés}

Vizsgálatunk tárgyát képező 10 éves időintervallum bölcsességfogai a Semmelweis Egyetem, Fogorvostudományi Kar, Arc-, Állcsont-, Szájsebészeti és Fogászati Klinika 65 dentoalveoláris- vagy maxillofaciális sebész szakorvosának, illetve rezidens orvosának neve alatt került eltávolításra. Dentoalveoláris ambulanciánk - szakellátó egységként - beutalókötelesen múködik, így a páciensek az alapellátás szürörendszerén keresztül kerülnek intézményünkbe, ahol az esetek kétharmadában - föként sebészi úton - alsó bölcsességfogakat távolítottunk el. A magyarázat nemzetközi összehasonlításban is az, hogy a felső bölcsességfogak eltávolítását jóval gyakrabban elvégzik az alapellátás keretein
A Semmelweis Egyetem

Arc-, Állcsont-, Szájsebészeti és Fogászati Klinikán 2010. január 1-tól 2019. szeptember 30-ig bölcsességfog eltávolításon átesett páciensek koreloszlása

\begin{tabular}{|l|r|}
\hline Életkor (év) & Esetszám $(\mathrm{db})$ \\
\hline $0-9$ & 3 \\
\hline $10-19$ & 2823 \\
\hline $20-29$ & 10479 \\
\hline $30-39$ & 5213 \\
\hline $40-49$ & 2359 \\
\hline $50-59$ & 971 \\
\hline $60-69$ & 868 \\
\hline $70-79$ & 458 \\
\hline $80-89$ & 123 \\
\hline $90-99$ & 8 \\
\hline Összesen: & 23305 \\
\hline
\end{tabular}

belül, mint az alsókét [43]. Ennek hátterében több ok is feltételezhető. Az egyik, hogy a felső bölcsességfogak eltávolítása egyszerübben kivitelezhető, jóval ritkábban igényel sebészi módszert. Contar és mtsai a felső bölcsességfogak 42,7\%-át távolították el kizárólag emelő segítségével osteotomia nélkül, ugyanez a technika az eltávolított alsó bölcsességfogak $2 \%$-ánál volt elégséges [12]. A másik ok, hogy a két állcsont bölcsességfo-

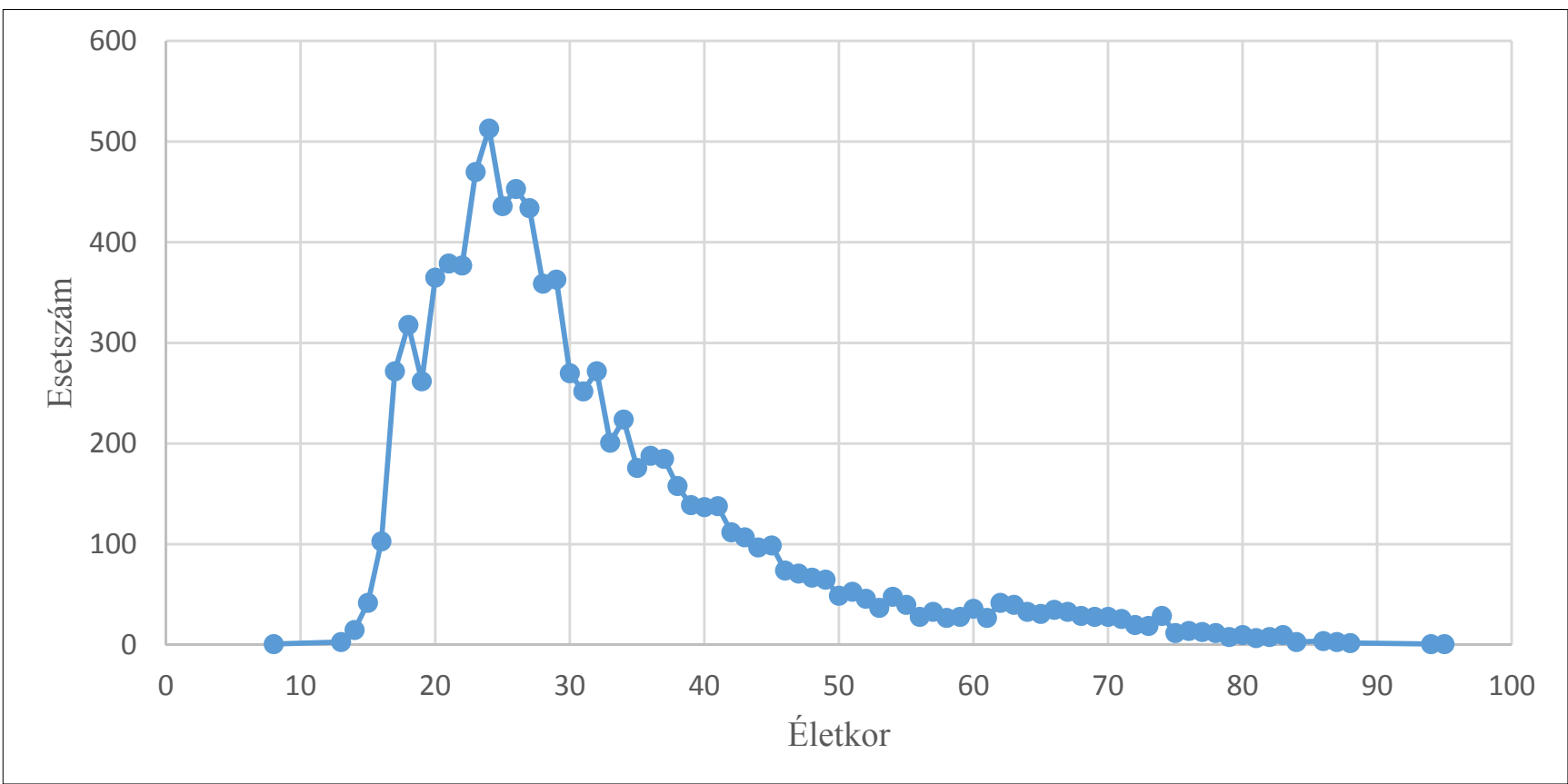

2. kép: A Semmelweis Egyetem, Fogorvostudományi Kar, Arc-, Állcsont-, Szájsebészeti és Fogászati Klinikán 2010-től 2019-ig felső bölcsességfog eltávolításon átesett páciensek koreloszlása 


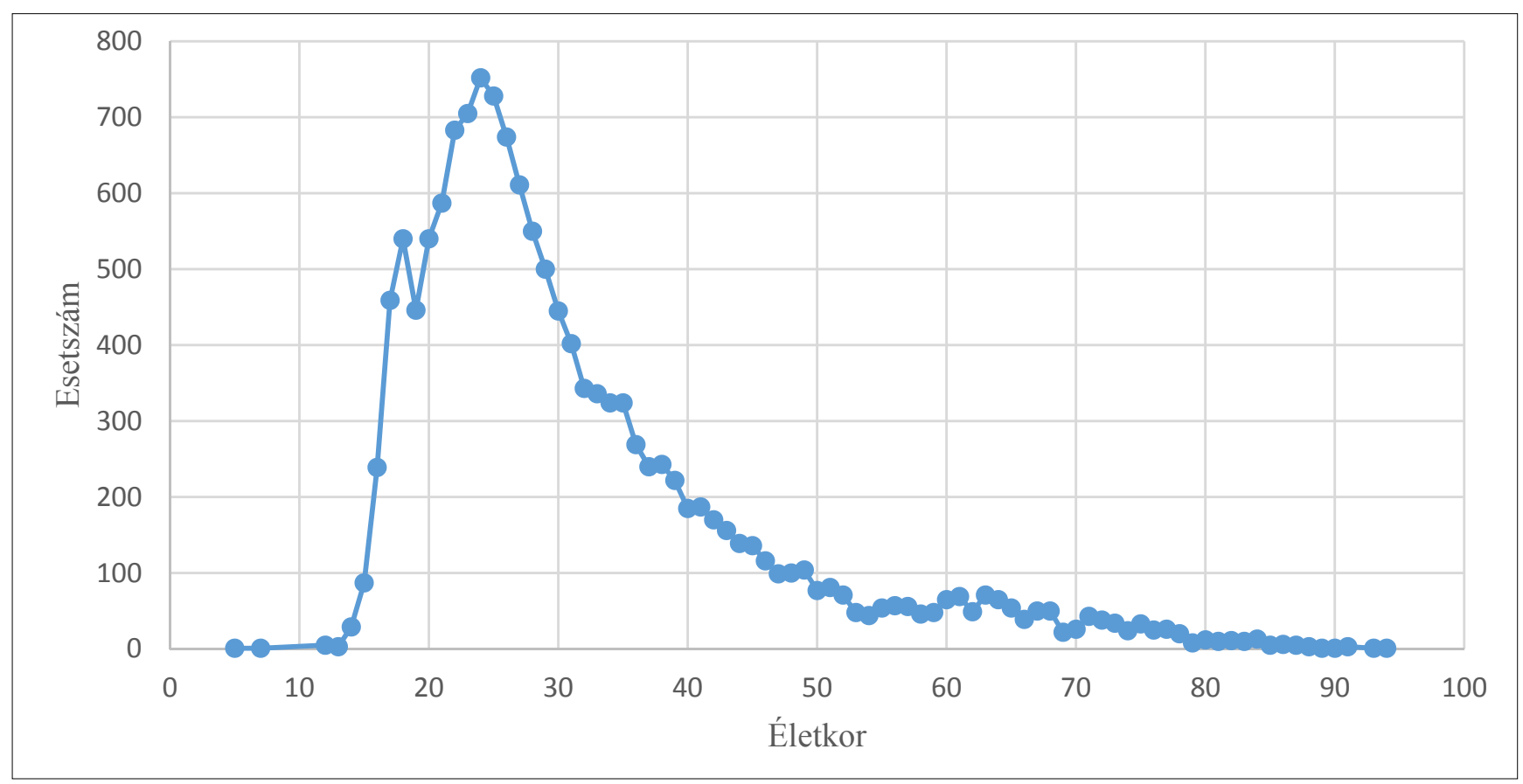

3. kép: A Semmelweis Egyetem, Fogorvostudományi Kar, Arc-, Állcsont-, Szájsebészeti és Fogászati Klinikán 2010-től 2019-ig alsó bölcsességfog eltávolításon átesett páciensek koreloszlása

gai közül az alsók okoznak gyakrabban panaszt. Ehhez társul, hogy az eltávolítást követő morbiditás, fájdalom, diszkomfort is jelentősebb esetükben, illetve a szövődmények is gyakoribbak [6, 12, 22]. Leggyakoribb komplikációk közt szerepel a nervus alveolaris inferior és a nervus lingualis sérülése, alveolitis, infekciók, vérzés, trismus, a szomszédos fogak iatrogén sérülése, illetve a peri-, és postoperativ mandibulafractura $[1,18]$. Eredményeink jelentős női dominanciát mutattak, amire a nemzetközi szakirodalomban találunk példát [27, 32, 43] és ellenpéldát is [25]. Hugoson és mtsai szerint egy svéd populációban impactio a férfiak esetében 30,4\%-ban, nők esetén pedig 43,8\%-ban volt jelen [21]. Tomaszewska és mtsai adatai alapján Lengyelországban a férfiak szignifikánsan ritkábban járnak fogorvoshoz, mint a nők [45]. Eredményeink széles kormegoszlást mutatnak, ám az átlagéletkornak számító 31 éves életkorban jóval kevesebb beavatkozást végeztünk, mint a fiatalabb korosztályoknál. Ennek oka, hogy jelentős számban olyan, idősebb pácienseken is szükséges volt bölcsességfog-eltávolítást végezni, akik gyakran csak a panaszok megjelenését követően jelentkeznek a fogorvosnál. A nemzetközi eredményeknek és ajánlásoknak megfelelően leggyakrabban 24 éves páciensek bölcsességfogait távolítottuk el, melynek oki magyarázatára a szakirodalom több kutatást is felvonultat $[9,10,34$, 37]. Chiapasco és mtsai a 24 éves kort, mely a foramen apicale záródásának leggyakoribb időpontja, tartják a profilaktikus bölcsességfog-eltávolítás felső határának. Ennek oka, hogy az idősebb korosztályokban már háromszorosára emelkedik a posztoperatív szövődmények száma. 17 éves kor alatt nem találtak szignifikáns eltérést a szövődmények előfordulásának gyakoriságában a 17-24 éves korosztályhoz képest, viszont 1724 éves korban könnyebben ítélhető meg, hogy valóban szükséges-e az adott fogak eltávolítása [9, 37]. Ellentétben azzal, hogy a bölcsességfogak eruptiójának időpontja fehér közösségekben átlagosan 17,8 és 24 év közé esik, nigériai afrikai populációkban 13-15 év között már gyakorta előtörtek a bölcsességfogak [44]. Kruger és mtsai új-zélandi tanulmánya szerint nagyjából 25 éves korig a szájüregben való megjelenést követően még lényeges változásokon mehet keresztül a bölcsességfogak pozíciója [29]. Ennek hátterében feltételezhető egyrészről a retromolaris tér méretének változása, mely az életkor előrehaladtával növekszik [19, 40]. Szintén megfigyelhető, hogy 20-23 éves életkor között az alsó bölcsességfogak verticalis irányba állásának valószínüsége növekvő tendenciát mutat. Ryalat és mtsai kutatása szerint a 20 évnél idősebbeknél az impactio $21,4 \%$-ban verticalis, és 11,7\%-ban horizontalis, míg ugyanez az arány 20 évnél fiatalbb páciensek esetében $14 \%$ és $21,3 \%$ [41]. Összességében véve egy 18 éves korban még impactioban lévő alsó bölcsességfog előtörésének valószínúsége $30-50 \%$. Kivételt képeznek ez alól a horizontális pozícióban impaktálódott bölcsességfogak [47]. Ezt követően is bekövetkezhet változás az impaktált bölcsességfogak eruptiós helyzetében, ez azonban messze alulmúlja az előtöréstől 25 éves korig tartó periódust [29]. A 25. életév után végzett bölcsességfog-eltávolítás az életkor előrehaladtával statisztikailag korrelál az alveolitis-, posztoperatív gyulladások-, parodontális károsodások-, illetve a sinus maxillaris perforatio kialakulásának gyakoriságával $[6,8,10,11,30$, 
36, 39]. Érdekes megállapítás, hogy az alsó bölcsességfogak mútéti eltávolításának egy ritka (az esetek 1,17\%-ában fellépő) szövődménye, a késői posztoperatív gyulladás (delayed-onset infection) főként fiatalokra jellemző. Egy klinikánkon végzett vizsgálat során a legidősebb páciens, akinél ilyen panasz jelentkezett, 22 éves volt [23]. Átlagéletkor tekintetében igen megoszló statisztikai eredményeket vonultat fel a nemzetközi szakirodalom. A University of Helsinki eredményeivel ellentétben - ahol az átlagéletkor 36,4 év, a medián életkor 32 év volt - klinikánk pácienseinek bölcsességfogai átlagosan korábbi életkorban kerültek eltávolításra [25]. A hazai gyakorlattól eltérően az Amerikai Egyesült Államokban az átlagéletkor - biztosítási okokból adódóan, illetve az American Association of Oral and Maxillofacial Surgeons álláspontját követve - 17-18 év [14, 15, 20]. Knutsson és mtsai Svédországban átlagosan 28 éves korban távolítottak el alsó bölcsességfogakat [27]. Aida és mtsai Japánban végzett vizsgálatok során azt találták, hogy a legtöbb bölcsességfogat 15 és 34 év között távolították el [3], míg az Egyesült Királyságban 1994 és 2012 között 29 éves korról 36 éves korra növekedett ez az átlagéletkor [35].

\section{Összefoglalás}

A bölcsességfogak megbetegedéseinek, illetve a velük összefüggésben lévő patológiás elváltozások prevalenciája világszerte jelentős a felnőtt populáció körében. Terápiás és preventív megoldásként is gyakran döntünk a bölcsességfogak extractiója mellett, melynek időzítése kulcsfontosságú. Az ideális életkor intervallumban végzett bölcsességfog-eltávolítások esetében a kóros elváltozások kialakulása nagyobb valószínúséggel előzhető meg, a mütéti szövődmények ritkábbak és kevésbé súlyosak. Retrospektív klinikai vizsgálatunk során azt találtuk, hogy 2010 és 2019 között leggyakrabban 23-24 éves páciensek bölcsességfogait távolítottuk el, ami nemzetközi ajánlásoknak megfelelően a mai napig is ideálisnak számít. Ennek ellenére a magyar lakosság egészségtudatosságának növelése, ez irányú fogászati prevenciójának fejlesztése, illetve a fogorvosok és szájsebészek preventív szemléletének erősítése elősegítené, hogy a jövőben több bölcsességfogat távolíthassunk el statisztikailag ideális életkorban, ezzel növelve pácienseink életminőségét. További értékes információkat nyerhetnénk a jövőben a vizsgált adataink kiegészítésével, feltüntetve a fogeltávolítás módját, nehézségét, a pontos diagnózist, illetve az esetleges szövődményeket is.

\section{Irodalom}

1. Adeyemo WL, James O, Ogunlewe M, Ladeinde A, Taiwo A, Olojede $O$ : Indications for extraction of third molars: A review of 1763 cases. Niger Postgrad Med J 2008; 15: 42-46.
2. AdeYemo WL: Do pathologies associated with impacted lower third molars justify prophylactic removal? A critical review of the literature. Oral Surg Oral Med Oral Pathol Oral Radiol Endod 2006; 102: 448-452. https://doi.org/10.1016/j.tripleo.2005.08.015

3. Aida J, Morita M, Akhter R, Aoyama H, Masul M, Ando Y: Relationships between patient characteristics and reasons for tooth extraction in Japan. Community Dent Health 2009; 26: 104109.

4. Al-Ogayel MO, Al-Suliman NA, Al-Forain OA. Al-Ziyadi YM, AlSadoon AS, Moosa $Z$, et al: The Prevalence of Impacted Third Molars and their Associated Pathologies in Adult Patients. Donnish Journals 2018; 4: 1-8.

5. Andersson L, Kahnberg KE, Pogrel MA: Oral and Maxillofacial Surgery, Wiley-Blackwell, United Kingdom, 2010; 195-215.

6. Bienstock DA, Dodson TB, Perrott DH, Chuang SK: Prognostic Factors Affecting the Duration of Disability After Third Molar Removal. Journal of Oral and Maxillofacial Surgery 2011; 69: 1272 1277. https://doi.org/10.1016/j.joms.2010.06.211

7. ByahatTI S, Ingafou MS: Prevalence of eruption status of third molars in Libyan students. Dental Research Journal 2012; 9: 152-157. https://doi.org/10.4103/1735-3327.95228

8. Chiapasco M, Crescentini M, Romanoni G: Germectomy or delayed removal of mandibular impacted third molars: the relationship between age and incidence of complications. Journal of Oral and Maxillofacial Surgery 1995; 53: 418-422. https://doi. org/10.1016/0278-2391(95)90715-7

9. Chiapasco M, De Cicco L, Marrone G: Side effects and complications associated with third molar surgery. Oral Surg Oral Med Oral Pathol 1993; 76: 412-420. https://doi.org/10.1016/0030 $-4220(93) 90005-O$

10. Chuang SK, Perrott DH, Susarla SM, Dodson TB: Age as a Risk Factor for Third Molar Surgery Complications. Journal of Oral and Maxillofacial Surgery 2007; 65: 1685-1692. https://doi.org/ 10.1016/j.joms.2007.04.019

11. Clauser B, Barone R, Briccoli L, Briccoli L, Baleani A: Complications in surgical removal of mandibular third molars. Minerva Stomatol 2009; 58: 359-366.

12. Dodson TB, SusArLa SM: Impacted wisdom teeth. BMJ Clin Evid 2014; 1302

13. EkLUNd SA, PItTMAN JL: Third-molar removal patterns in an insured population. J Am Dent Assoc 2001; 132: 469-75. https:// doi.org/10.14219/jada.archive.2001.0209

14. Friedmann JW: The Prophylactic Extraction of Third Molars: A Public Health Hazard. American Journal of Public Health 2007; 97: 1554-1559. https://doi.org/10.2105/AJPH.2006.100271

15. Fuster-Torres MA, Gargallo-Albiol J, Ber- INI-Aytes L, Gay-EsCODA C: Evaluation of the indication for surgical extraction of third molars according to the oral surgeon and the primary care dentist. Experience in the Master of Oral Surgery and Implantology at Barcelona University Dental School. Med Oral Patol Oral Cir Bucal 2008; 13: 499-504.

16. Gyulai-GaÁl Sz, MinYa F: Áttörésben visszamaradt bölcsességfogak ellátása az ambuláns szájsebészeti gyakorlatban egy év adatai alapján. Fogorv Szle 2019; 5-9.

17. Hashemipour MA, Tahmasbi-Arashlow M, Fahimi-Hanzael F: Incidence of impacted mandibular and maxillary third molars: A radiographic study in a Southeast Iran population. Med Oral Patol Oral Cir Bucal 2013; 18: 140-145. https://doi.org/10.4317/medoral. 18028

18. Hattab FN, Rawashdeh MA, Fahmy MS: Impaction status of third molars in Jordanian students. Oral Surg Oral Med Oral Pathol Oral Radiol Endod 1995; 79: 24-29. https://doi.org/10.1016/ S1079-2104(05)80068-X

19. https://www.aaoms.org/docs/practice_resources/clinical_resources/ impacted_third_molars.pdf?fbclid=IwAR3iKEIdH5ZBAFmZ7fnN6 rXn5naBcgj6ollE1HeHE6lj_MfFkX8yP-9pnM

20. Hugoson A, Kugelberg CF: The prevalence of third molars in a Swedish population. An epidemiological study. Community Dent Health 1988; 5: 121-38. 
21. JoÓB-FANCSALY Á: A bölcsességfogak szerepe a fogászat különböző szakterületein. Semmelweis Kiadó, Budapest, 2010; 29-104.

22. KaposvárI I, Körmöczi K, Horváth $F$, Buglyó A, Tural A, JoóbFANCSALY Á: Az alsó bölcsességfogak mútéti eltávolítását követő késői posztoperatív gyulladás (delayed-onset infection) vizsgálata. Orvosi Hetilap 2018; 159: 1278-1283. https://doi.org/10.1556/ 650.2018.31134

23. Katsarou T, Kapsalas A, Souliou C, Stefaniotis T, Kalyvas D: Pericoronitis: A clinical and epidemiological study in greek military recruits. J Clin Exp Dent 2019; 11 (2): 133-137. https://doi. org $/ 10.4317 /$ jced. 55383

24. Kautto A, VehKalahti MM, Ventä I: Age of patient at the extraction of the third molar. Int J Oral Maxillofac Surg 2018; 47: 947-951. https://doi.org/10.1016/j.ijom.2018.03.020

25. Khan I, Halli R, Gadre P, Gadre KS: Correlation of panoramic radiographs and spiral $C T$ scan in the preoperative assessment of intimacy of the inferior alveolar canal to impacted mandibular third molars. J Craniofac Surg 2011; 22: 566-570. https://doi.org/ 10.1097/SCS.0b013e3182077ac4

26. KÖRMÖCZI K, BogdÁN S, JoóB-FAnCSALY Á: Bölcsességfogak koronektómiája és annak szövődményei. Fogorv Szle 2018; 111: 79-84.

27. Knutsson K, Brehmer B, Lysell L, Rohlin M: Pathoses associated to third molars subjected to removal. Oral Surg Oral Med Oral Pathol Oral Radiol Endod 1996; 82: 10-17. https://doi.org/ 10.1016/S1079-2104(96)80371-4

28. Kruger E, Thomson WM, Konthasinghe P: Third molar outcomes from the age 18 to 26: findings from a population-based New Zealand longitudinal study. Oral Surgery, Oral Medicine, Oral Pathology, Oral Radiology, and Endodontology 2001; 92: 150-155. https://doi.org/10.1067/moe.2001.115461

29. Kugelberg CF: Periodontal healing two and four years after impacted lower third molar surgery. A comparative retrospective study. Int J Oral Maxillofac Surg 1990; 19: 341-345. https://doi. org/10.1016/S0901-5027(05)80077-3

30. LYSELL L, ROHLIN M: A study of indications used for removal of the mandibular third molar. Int J Oral Maxillofac Surg 1988; 17: 161164. https://doi.org/10.1016/S0901-5027(88)80022-5

31. Magraw CBL, Moss KL, Fisher EL, Offen- bacher S, White JR RP: Prevalence of visible third molars in the United States population: How many individuals have third molars. J Oral Maxillofac Surg 2016; 74: 13-17. https://doi.org/10.1016/j.joms.2015.08.009

32. Muhonen A., Ventä I., \& YlipaAvalniemi P: Factors Predisposing to Postoperative Complications Related to Wisdom Tooth Surgery Among University Students. J Am Coll Health 1997; 46: 39-42. https://doi.org/10.1080/07448489709595585

33. Osborn TP, Frederickson G, Small IA, Torgerson TS: A prospective study of complications related to mandibular third molar surger. J of Oral and Maxillofac Surg 1985; 43: 767-769. https://doi. org/10.1016/0278-2391(85)90331-3
34. Petrosyan V, Ameerally P: Changes in Demographics of Patients Undergoing Third Molar Surgery in a Hospital Setting between 1994 and 2012 and the Influence of the National Institute for Health and Care Ex-cellence Guidelines. J Oral Maxillofac Surg 2014; 72: 254-258. https://doi.org/10.1016/j.joms.2013.09.029

35. Phillips $C$, White RP JR, Shugars DA, Shugars DA, Zhou X: Risk factors associated with prolonged healing after third molar surgery. J Oral Maxillofac Surg 2003; 61: 1436-1438. https://doi.org/ 10.1016/j.joms.2003.08.003

36. Pogrel MA: What is the effect of timing of removal on the incidence and severity of complications? J Oral Maxillofac Sur 2012; 70: 37-40. https://doi.org/10.1016/j.joms.2012.04.028

37. Renton T, Al-Haboubi M, Pau A, Shepherd J, Gallagher JE: What has been the United Kingdom's experience with retention of third molars. J Oral Maxillofac Surg 2012; 70: 48-57. https://doi.org/ 10.1016/j.joms.2012.04.040

38. Rothamel D, Wahl G, d' Hoedt B, Nentwig GH, Schwarz F, Becker J: Incidence and predictive factors for perforation of the maxillary antrum in operations to remove upper wisdom teeth: Prospective multicentre study. British Journal of Oral and Maxillofacial Surgery 2007; 45: 387-391. https://doi.org/10.1016/j.bjoms.2006. 10.013

39. Różyło-Kalinowska I, Burdan F, Marchut T: Morphology of third molar teeth with incompletely formed apices on the basis of panoramic radiograms. Folia Morphol (Warsz) 2003; 62: 1-9.

40. Ryalat S, Kassob Z, Hassona Y, Al-Shayyab MH, Sawair F: Impaction of lower third molars and their association with age: radiological perspectives. BMC Oral Health 2018; 18: 58. https://doi.org/ 10.1186/s12903-018-0519-1

41. Santosh P. Impacted Mandibular Third Molars: Review of Literature and a Proposal of a Combined Clinical and Radiological Classification. Ann Med Health Sci Res 2015; 5: 229-234. https://doi. org/10.4103/2141-9248.160177

42. SUSARLA SM, Dodson TB: Predicting third molar surgery operative time: A validated model. J Oral Maxillofac Surg 2013; 71: 5-13. https://doi.org/10.1016/j.joms.2012.08.004

43. SzALMA J: A panorámaröntgen szerepe a nervus alveolaris inferior sérülések kockázatának megítélésében alsó bölcsességfogak mútéti eltávolításakor. Doktori értekezés, 2011

44. Tomaszewska, A., Sikora M: The incidence and extraction causes of third molars among young adults in Poland. Anthropological Review 2019; 82: 253-263. https://doi.org/10.2478/anre-2019 $-0018$

45. van der Linden W, Cleaton-Jones P, Lownie M: Diseases and lesions associated with third molars. Oral Surg Oral Med Oral Pathol Oral Radiol Endod 1995; 79: 142-145. https://doi.org/10.1016/ S1079-2104(05)80270-7

46. VENTA I: Predictive model for impaction of lower third molars. Oral Surg Oral Med Oral Pathol 1993; 76: 699-703. https://doi.org/ 10.1016/0030-4220(93)90037-5 
Papp Zs K, SzmiRnov Gy, Csomó K, IvánYI A, Joób-F Á

\section{The role of age in third molar surgery: a retrospective study}

The aim of our study was to compare our clinical database of removed third molars with the international results, focusing on the patients' age. As being one of the most frequently visited dentoalveolar surgical centers with the highest number of employed dentoalvolar surgeons in Hungary, it is a great opportunity to get valuable informations from our patient database compared to other foreign surgical centers. Our research covered a ten years period from 2010-2019. Informations were gathered about gender, age and position of the affected teeth. A total of 23305 third molars were removed from patients 5 to 95 years of age in the mentioned period. Our measured datas were compared to other international study results. Surgical third molar removal was carried out more often in women $(61,5 \%)$ than in men $(38,5 \%)$, which is not corresponding to results gathered from international surgical centers. Removal of the third molar from the lower jaw was carried out in about two thirds of the total cases $(60,7 \%)$. The most significant age of the surgical removal was 24 years of age, both in the upper and the lower jaw. No significal differences were found in age neither between upper and lower jaw nor between the four quadrants in comparison. Heterogenity in gathered data and in social insurance codification was resulted in a lack of statistical evaluation from the accurate diagnose and the method of tooth removal.

Keywords: third molar, extraction, operation, age, gender, distribution 